\title{
PERBANDINGAN LATIHAN BOLA DIGANTUNG DAN BOLA DILAMBUNGKAN TERHADAP HASIL BELAJAR SEPAK MULA DALAM PERMAINAN SEPAK TAKRAW PADA SISWA PUTRA KELAS X-IS 1 SMA 17 AGUSTUS 1945 SURABAYA
}

\author{
Moh. Hanafi ${ }^{1}$, Brahmana Rangga $\mathbf{P}^{2}$ \\ ${ }^{1,2}$ Dosen Prodi Pendidikan Kepelatihan Olahraga, Fakultas Keguruan dan Ilmu \\ Pendidikan, Universitas PGRI Adi Buana Surabaya \\ email : hanafi_takrawjatim@yahoo.com ${ }^{1}$, r_brahmana@yahoo.co.id ${ }^{2}$
}

\begin{abstract}
ABSTRAK
Permainan sepak takraw adalah jenis permainan tradisional yang telah berkembang dan banyak dikenal oleh masyarakat Indonesia. Permainan sepak takraw meskipun berkembang baik di masyarakat tetapi di sekolah-sekolah khususnya pembinaan cabang olahraga ini agak terlambat karena kurangnya tenaga pembina, pelatih dan guru pendidikan jasmani yang menguasai teknik, taktik dan seluk beluk tentang permainan sepak takraw. Populasi dalam penelitian ini adalah siswa putra kelas X SMA 17 Agustus 1945 Surabaya tahun pelajaran 2016/2017 yang terdiri dari 105 siswa. Sedangkan subjek sampel dalam penelitian adalah siswa putra kelas X-IS 1 SMA 17 Agustus 1945 Surabaya yang berjumlah 20 siswa dengan menggunakan metode random sampling.Teknik pengumpulan data dalam penelitian ini menggunakan metode eksperimen semu atau memberikan perlakuan (treatment) yang diberikan kepada siswa putra kelas X-IS 1 SMA 17 Agustus 1945 Surabaya tahun pelajaran 2016/2017 yang diambil sebanyak 20 siswa. Sedangkan melihat mean hasil akhir kelompok yang dilatih sepak mula bola digantung sebesar 19,05 dan mean hasil akhir kelompok yang dilatih sepak mula bola dilambungkan yaitu sebesar 10,05 membuktikan bahwa hipotesis yang mengatakan latihan sepak mula bola digantung lebih baik hasilnya dari pada latihan sepak mula bola dilambungkan terhadap hasil sepak mula dalam permainan sepak takraw siswa putra kelas X-IS 1 SMA 17 Agustus 1945 Surabaya diterima.
\end{abstract}

Kata kunci: hasil belajar, latihan bola digantung, bola dilambungkan, sepak takraw.

\section{A. PENDAHULUAN}

Permainan sepak takraw adalah jenis permainan tradisional yang telah berkembang dan banyak dikenal oleh masyarakat Indonesia. Yang menarik dalam olahraga ini adalah sarana prasarananya murah dan sangat sederhana, olahraga ini mengandung akrobatik yang menarik dan dapat dimainkan oleh seluruh lapisan masyarakat sehingga pemain merasa bangga jika dapat mempertontonkan kemahiran memainkan bola, dan bagi yang menyaksikannya akan terhibur dengan atraksiatraksi yang disuguhkan. Akan tetapi pada kenyataannya sepak takraw belum sepopuler sepak bola ataupun bola voli jika dilihat dari peminatnya. Kedua cabang tersebut dimainkan tidak hanya oleh masyarakat umum tetapi juga sudah menjadi program kegiatan ekstrakurikuler di sekolah-sekolah, dari sekolah dasar sampai perguruan tinggi dan dapat berjalan dengan baik dibawah bimbingan pelatih atau guru pendidikan jasmani yang betul-betul menguasai dan memahami dibidangnya, sehingga dapat mencapai prestasi yang optimal. Semua itu adanya dukungan pembinaan yang baik secara terus-menerus dari mulai pemassalan, pembibitan sampai pembentukan prestasi. 
Permainan sepak takraw meskipun berkembang baik di masyarakat tetapi di sekolah-sekolah khususnya pembinaan cabang olahraga ini agak terlambat karena kurangnya tenaga pembina, pelatih dan guru pendidikan jasmani yang menguasai teknik, taktik dan seluk beluk tentang permainan sepak takraw. Sepak takraw merupakan cabang olahraga tradisional yang sedikit unik dibanding olahraga lainnya, keunikan sepak takraw seperti yang kita ketahui dominannya pada unsur senam dan akrobatik sebagai dasar keterampilan menuju kematangan prestasi, dari pemikiran ini dapat digaris bawahi bahwa tanpa pembinaan sejak dini akan sulit melahirkan atlit yang berprestasi optimal (Sasmito, 2004: 2).

Untuk bermain sepak takraw yang baik seseorang pemain harus mempunyai kemampuan atau keterampilan yang baik. Kemampuan yang penting dan perlu dalam sepak takraw adalah kemampuan dasar bermain. Bila seseorang tidak mempunyai kemampuan itu tidak akan dapat bermain sepak takraw. Kemampuan yang dimaksud adalah menyepak dengan menggunakan bagianbagian kaki, memainkan bola dengan kepala memainkan bola dengan dada, memainkan bola dengan paha dan memainkan bola dengan bahu.

Dalam permainan sepak takraw, menyepak (sepakan) adalah sangat penting. Dapat dikatakan kemampuan menyepak merupakan ibu dari permainan sepak takraw karena bola sebagian besar dimainkan dengan kaki, mulai dari permulaan permainan sampai membuat angka dapat dilakukan dengan kaki (sepakan) (Darwis dan Basa, 1992:16). Selain teknik dasar yang dimaksud di atas seorang pemain juga harus memiliki teknik khusus, yaitu sepak mula, smash dan blok (Darwis dan Basa, 1992:60).

Kelemahan dari sepak mula adalah dalam membuat angka dengan sepak mula yang keras khususnya di tekong, akibatnya banyak sepak mula tersebut bolanya menyangkut net/jaring/keluar lapangan permainan. Hal tersebut sangatlah merugikan sebab hendaknya tujuan sepak mula hendaknya ditujukan kepada pengacauan permainan atau pertahanan bahwa sehingga kita dapat mengatur serangan-serangan yang mantap pada lawan. Melakukan sepak mula tidak hanya harus kencang tetapi juga harus diarahkan untuk merusak permainan/pertahanan lawan. Seorang tekong hendaklah dapat membuat sepak mula yang baik dan dapat sasaran tepat dimana pertahanan lawan lemah dan sulit menerima bola sepak mula.

Sepak mula atau servis adalah sepakan yang dilakukan oleh tekong ke arah lapangan lawan sebagai cara memulai permainan (Darwis dan Basa, 1992:61). Sepak mula atau servis merupakan cara kerja yang penting dalam sepak takraw, karena angka dapat diperoleh regu yang melakukan sepak mula. Kegagalan dalam sepak mula berarti hilangnya kesempatan regu untuk mendapatkan angka, sebaliknya memberi peluang pihak lawan untuk mendapatkan angka. Banyak pemain (tekong) yang mencoba membuat angka dengan sepak mula yang keras saja. Oleh sebab itu mereka selalu melakukan sepak mula dengan keras. Akibatnya banyak sepak mula tersebut menyangkut pada jaring atau keluar lapangan permainan. Hal tersebut sangatlah merugikan. Melakukan sepak mula tidak hanya harus kencang dan keras tetapi juga harus diarahkan untuk merusak permainan atau pertahanan lawan. Seorang tekong hendaknya dapat membuat sepak mula yang baik dan dapat menentukan sasaran tempat-tempat dimana pertahanan lawan lemah dan sulit menerima sepak mula.

Berdasarkan uraian di atas yang telah menjadi alasan pemilihan judul adalah sebagai berikut, selama ini belum banyak sekolah yang memprogramkan olahraga sepak takraw sebagai kegiatan ekstrakurikuler. Kurangnya tenaga pembina, pelatih atau guru pendidikan jasmani yang menguasai teknik, taktik serta seluk beluk tentang sepak takraw. Pentingnya penguasaan tehnik dasar dan tehnik khusus dalam permainan sepak takraw. Sepak mula sebagai tehnik khusus harus benar-benar dikuasai oleh pemain (tekong). Adanya beberapa variasi bentuk latihan sepak mula yang dapat meningkatkan hasil sepak mula dalam permainan sepak takraw. Beberapa 
pelatih banyak mengembangkan latihan sepak mula dengan bola digantungkan dan bola dilambungkan sendiri. Belum adanya penelitian ilmiah yang meneliti tentang pengaruh latihan sepak mula dengan bola digantung dan bola dilambungkan sendiri.

\section{- Rumusan Masalah}

Bentuk latihan sepak mula dapat dilakukan dengan berbagai cara diantaranya latihan dengan bola digantung dan bola dilambungkan sendiri. Berdasarkan uraian tersebut di atas maka yang menjadi permasalahan dalam penelitian ini adalah:

1. Adakah perbedaan antara latihan bola digantung dan latihan bola dilambungkan terhadap hasil belajar sepak mula pada siswa putra kelas X-IS 1 SMA 17 Agustus 1945 Surabaya tahun pelajaran 2016/2017?

2. Manakah yang lebih baik antara bola digantung dengan bola dilambungkan terhadap hasil belajar sepak mula pada siswa putra kelas X-IS 1 SMA 17 Agustus 1945 Surabaya tahun pelajaran 2016/2017?

\section{- Tujuan Penelitian}

Tujuan dari penelitian ini adalah:

1. Untuk mengetahui perbedaan antara latihan bola digantung dan latihan bola dilambungkan terhadap hasil belajar sepak mula pada siswa putra kelas X-IS 1 SMA 17 Agustus 1945 Surabaya tahun pelajaran 2016/2017.

2. Untuk mengetahui mana yang lebih baik antara latihan bola digantung dan bola dilambungkan terhadap hasil belajar sepak mula pada siswa putra kelas X-IS 1 SMA 17 Agustus 1945 Surabaya tahun pelajaran 2016/2017.

\section{- Manfaat Penelitian}

Manfaat dari penelitian ini adalah:

1. Sebagai batas kajian untuk melakukan koreksi penguji ulang terhadap hasil dan metode latihan yang telah ada, sehingga hasil yang dicapai dapat memberi sumbangan keilmuan terhadap khasanah perbendaharaan kajian olahraga permainan khususnya sepak takraw.

2. Penelitian ini bisa digunakan sebagai bahan perbandingan bagi peneliti yang berminat untuk mengadakan penelitian tentang teknik-teknik khusus permainan sepak takraw, khususnya sepak mula.

\section{B. METODE PENELITIAN}

\section{- Jenis dan Desain Penelitian}

Jenis penelitian dari penelitian ini adalah eksperimen. Penelitian eksperimen adalah suatu penelitian yang dilakukan secara ketat untuk mengetahui hubungan sebab akibat diantara variabel-variabel. Salah satu ciri pokok dari penelitian eksperimen adalah adanya perlakuan (treatment) yang diberikan kepada subjek penelitian (Maksum, 2008:10).

Desain penelitian merupakan sebuah rancangan bagaimana suatu penelitian akan dilakukan (Maksum, 2008: 47).

Desain yang diteliti adalah:

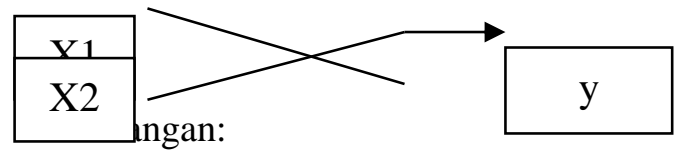

$\mathrm{X} 1$ : bola digantung

$\mathrm{X}$ 2: bola dilambungkan

$\mathrm{Y}$ : hasil belajar sepak mula dalam permainan sepak takraw

\section{- Populasi dan Sampel}

Populasi dalam penelitian ini adalah 105 siswa putra kelas X SMA 17 Agustus 1945 Surabaya.

Dalam penelitian ini yang menjadi sampel ini adalah siswa putra kelas X-IS yang terpilih karena memenuhi syarat sebagai anggota sampel. Dimana syarat tersebut adalah siswa kelas $\mathrm{X}$ dan siswa putra. Teknik pengambilan sampel dalam penelitian ini menggunakan teknik random sampling yaitu dengan mengikutkan 20 siswa putra kelas X-IS 1 yang diambil berdasarkan pengamatan tes sepak mula.

\section{- Instrumen Penelitian}

Instrumen dalam penelitian ini adalah menggunakan tes keterampilan sepak takraw

Tabel 1. Rangkuman Hasil Analisis Data auaran arat unur yally uryulanall untun mengumpulkan data dalam penelitian. Secara 
One-Sample Test

\begin{tabular}{|c|c|c|c|c|c|c|}
\hline & \multicolumn{6}{|c|}{ Test Value $=0$} \\
\hline & \multirow[b]{2}{*}{$\mathrm{t}$} & \multirow[b]{2}{*}{$\mathrm{f}$} & \multirow{2}{*}{$\begin{array}{l}S \\
\text { ig. }(2- \\
\text { tailed } \\
) \\
\end{array}$} & \multirow{2}{*}{$\begin{array}{c}\text { Mean } \\
\text { Differen } \\
\text { ce }\end{array}$} & \multicolumn{2}{|c|}{$\begin{array}{c}95 \% \\
\text { Confidence Interval } \\
\text { of the Difference }\end{array}$} \\
\hline & & & & & Lower & Upper \\
\hline $\begin{array}{l}\text { Skor__ } \\
\text { dilambu } \\
\text { ng }\end{array}$ & $\begin{array}{r}11.25 \\
6\end{array}$ & 19 & .000 & $\begin{array}{r}10.0500 \\
0\end{array}$ & 8.1812 & $\begin{array}{r}11.918 \\
8\end{array}$ \\
\hline $\begin{array}{l}\text { Skor__ } \\
\text { digantun } \\
\text { g }\end{array}$ & $\begin{array}{r}19.82 \\
3\end{array}$ & 19 & .000 & $\begin{array}{r}19.0500 \\
0\end{array}$ & $\begin{array}{r}17.038 \\
6\end{array}$ & $\begin{array}{r}21.061 \\
4\end{array}$ \\
\hline
\end{tabular}

garis besar, alat pengumpul data ada 2 kategori yaitu test dan non test. Tapi data yang digunakan disini memakai sistem test. Test adalah sebuah prosedur yang sistematis dan obyektif untuk memperoleh data/keterangan yang diinginkan dengan cara relatif tepat.

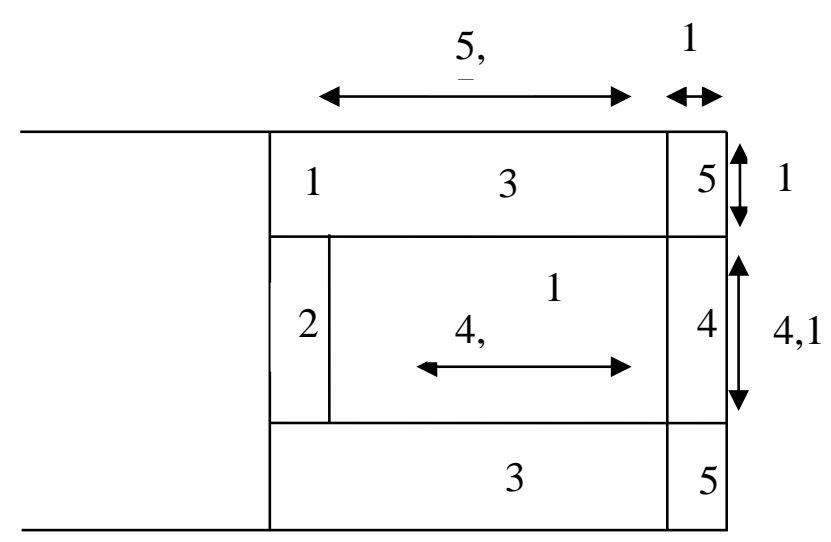

Gambar 1.

Lapangan Sepak Takraw untuk Tes Sepak Mula (Darwis dan Basa, 1992.: 120)

Berikut ini prosedur pelaksanaan tes:

1. Sampel dipanggil satu persatu menurut daftar yang telah disusun

2. Sampel yang telah dipanggil memasuki lapangan dan pada posisi siap untuk melakukan sepak mula.

3. Setelah pengumpan dan peserta tes siap maka tes segera dimulai.

4. Pengumpan melambungkan bola ke arah pesrta tes yang telah siap di daerah lingkaran tekong untuk melakukan sepak mula dengan lemparan setinggi lutut. Kesempatan melakukan sepak mula adalah sebanyak sepuluh kali. Sepak mula dianggap sah apabila tepat jatuh di tempat sasaran yang telah ditentukan nilainya. Jika bola jatuh diantara dua sasaran nilai yang dihitung adalah nilai yang besar. Dan sepak mula yang dianggap gagal apabila bola menyangkut di net dan jika bola keluar atau jatuh diluar lapangan.

5. Nilai akhir adalah jumlah skor yang didapat dari jumlah sepuluh kali sepak mula yang telah dilakukan.

6. Latihan servis dengan cara bola dilambungkan sendiri dan pengumpan yang dibantu oleh pelatih.

7. Gambar lapangan yang digunakan untuk tes sepak mula.

\section{HASIL DAN KESIMPULAN}

\section{- Hasil Penelitian}

Setelah dilaksanakan tes akhir, maka didapat data dari tiap-tiap subjek pada kelompok eksperimen yang diberi latihan sepak mula dengan cara bola dilambungkan. Hasil tersebut kemudian dimasukkan ke dalam tabel hasil pengolahan data Test dengan $\mathrm{T}$ Test.

Dari perhitungan statistik diperoleh thitung bola yang dilambungkan 11,25 dan bola digantung diperoleh t-hitung 19,82 lebih besar dari pada tabel yaitu 1,73 dengan signifikasi $5 \%$ derajat kebebasan $(\mathrm{db}) 20-1=19$. Berarti nilai bola dilambungkan lebih besar dari pada nilai bola digantung adalah melebihi batas penolakan $t$ dalam tabel 1,73. Dengan demikian perumusan hasil hipotesis nihil yang menyatakan "tidak ada peredaan yang berarti antara latihan sepak mula dengan bola digantung dan bola dilambungkan terhadap hasil belajar sepak mula dalam permainan sepak takraw" ditolak, sehingga hipotesis kerja yang diajukan yaitu "ada perbedaan antara latihan sepak mula dengan bola digantung dan bola dilambungkan terhadap hasil belajar sepak mula dalam permainan sepak takraw" diterima. Untuk penjelasan lebih lanjut lihat pada lampiran.

- Hasil latihan sepak mula dengan bola digantung

Setelah diadakan tes akhir diperoleh hasil mean dari kelomok eksperimen adalah sebagai berikut: 
- Hasil latihan sepak mula dengan bola dilambungkan

Setelah diadakan tes akhir diperoleh hasil mean dari kelompok kontrol adalah sebagai berikut:

Melihat hasil penelitian dan perhitungan statistik untuk menguji hipotesis taraf signifikasi 5\% derajat kebebasan (db) 19 pada tabel nilai-nilai terdapat sebesar 1,73. Dalam hal ini yang diperoleh dari hasil penelitian menunjukkan adanya perbedaan yang berarti antara latihan sepak mula bola digantung dan bola dilambungkan.

Sedangkan melihat mean hasil akhir kelompok yang dilatih sepak mula bola digantung sebesar 19,05 dan mean hasil akhir kelompok yang dilatih sepak mula bola dilambungkan yaitu sebesar 10,05 membuktikan bahwa hipotesis yang mengatakan latihan sepak mula bola digantung lebih baik hasilnya dari pada latihan sepak mula bola dilambungkan terhadap hasil sepak mula dalam permainan sepak takraw siswa putra kelas X IS-1 SMA 17 Agustus 1945 Surabaya diterima.

Dari hasil penelitian dan perhitungan statistik membuktikan bahwa latihan sepak mula bola digantung lebih baik dibandingkan latihan sepak mula dengan bola dilambungkan karena badan searah dengan sasaran yang diinginkan sehingga memudahkan dalam koordinasi antara pandangan dan gerak kaki, koordinasi antara indera penglihatan dan motorik didukung oleh posisi badan yang memungkinkan maka dapat menghasilkan koordinasi yang baik, sehingga timing tepat pada saat melakukan sepakan, ketepatan reaksi dan gerak.

Menyepak akan lebih baik karena didukung oleh konsentrasi yang sempurna antara indera penglihatan dan motorik. Untuk mengarahkan bola sesuai sasaran yang diinginkan lebih mudah karena sasaran terlihat jelas searah dengan posisi badan yang mengarah kelapangan lawan. Sebaliknya sepak mula dilambungkan kurang baik, karena konsentrasi terbagi dua yaitu untuk melambungkan bola dan persiapan pada saat
Tabel 2. Hasil latihan sepak mula dengan bola digantung

\begin{tabular}{|l|c|c|c|c|}
\hline & $\mathrm{N}$ & Mean & $\begin{array}{c}\text { Std. } \\
\text { Deviation }\end{array}$ & $\begin{array}{c}\text { Std. Error } \\
\text { Mean }\end{array}$ \\
\hline Skor_- & & & &
\end{tabular}

Tabel 3. Hasil latihan sepak mula dengan bola dilambungkan

\begin{tabular}{|l|c|r|c|c|}
\hline & $\mathrm{N}$ & Mean & $\begin{array}{c}\text { Std. } \\
\text { Deviation }\end{array}$ & $\begin{array}{c}\text { Std. Error } \\
\text { Mean }\end{array}$ \\
\hline $\begin{array}{l}\text { Skor__ } \\
\text { dilambun } \\
\text { g }\end{array}$ & 20 & $\begin{array}{r}10.05 \\
0\end{array}$ & 3.99309 & .89288 \\
\hline
\end{tabular}

melakukan sepak mula. Hal ini terjadi karena konsentrasi terjadi antara pengaturan keseimbangan dan koordinasi gerak, maka menjadikan keseimbangan kurang baik.

\section{- Kesimpulan}

Berdasarkan hasil penelitian dan pembahasan dapat disimpulkan sebagai berikut:

1. Ada perbedaan yang berarti antara latihan sepak mula bola digantung dan bola dilambungkan terhadap hasil sepak mula siswa putra kelas X IS-1 SMA 17 Agustus 1945 Surabaya tahun pelajaran 2016-2017.

2. Latihan sepak mula bola digantung lebih baik hasilnya dari pada latihan sepak mula dengan cara bola dilambungkan terhadap hasil sepak mula siswa putra kelas X IS-1 SMA 17 Agustus 1945 Surabaya tahun pelajaran 2016-2017.

\section{- Saran}

Latihan sepak mula digantung mempunyai pengaruh yang lebih baik dari pada latihan sepak mula dengan bola dilambungkan terhadap hasil sepak mula dalam sepak takraw, untuk itu disarankan:

1. Latihan sepak mula dengan cara bola digantung dapat meningkatkan kemampuan sepak mula dalam sepak takraw.

2. Hendaknya para pelatih sepak takraw dapat memakai metode latihan sepak mula 
dengan cara digantung dalam latihan sepak mula pada permainan sepak takraw.

3. Penelitian ini dapat digunakan sebagai bahan pembanding bagi peneliti lain berniat mengadakan penelitian serupa

\section{DAFTAR RUJUKAN}

Darwis, Ratinus dan Basa, Penghulu, 1992. Olahraga Pilihan Sepak Takraw. Jakarta: Depdikbud

Hadi, Sutrisno. 2000. Statistik Jilid I. Yogyakarta: Penerbit Andi

Hakim, Abdul Azis. 2007. Sepak takraw, Surabaya: Universitas Negeri Surabaya.

Harsono. 1988. Coaching dan Aspek-Aspek Psikologis Dalam Coaching. Jakarta: PPLPTK.

Maksum, Ali. 2007. Statistik dalam Olahraga, Surabaya: Universitas Negeri Surabaya.

Maksum, Ali. 2008. Metode Penelitian. Surabaya: Universitas Negeri Surabaya.

Prawirasaputra, Sudrajat. 2000. Sepak Takraw, Jakarta: Departemen Pendidikan Nasional

Sasmito, Ali. 2004. Perbedaan Hasil Sepak Mula Antara Sajian Bola Setinggi Dada dan Setinggi Pinggang dalam Permainan Sepak Takraw. Surabaya: Skripsi Universitas Negeri Surabaya.

Suhud, Muhammad. 1991. Sepak Takraw. Jakarta: Balai Pustaka.

Sugiyono. 2008. Metode Penelitian Kuantitatif Kualitatif dan $R$ dan $D$. Bandung: Alfabeta Bandung.

Arikunto, Suharsimi, 2006. Prosedur Penelitian Suatu Pendekatan Praktek Revisi VI. Jakarta: Bina aksara.

Supranto, J. 2007. Statistik, Jakarta: Erlangga

Surakhmad,Winarno. 1990. Pengantar Penelitian Ilmiah Dasar Metode dan Teknik. Bandung: Torsilo.

Winarno, 2010. Metodologi Penelitian Dalam Pendidikan Jasmani. Malang: IKIP Budi Utomo Malang 